\title{
SURFACE ROUGHNESS OF THIN-WALLED COMPONENTS MADE OF ALUMINIUM ALLOY EN AW-2024 FOLLOWING DIFFERENT MILLING STRATEGIES
}

\author{
Józef Kuczmaszewski', Paweł Pieśko' ${ }^{1}$, Magdalena Zawada-Michałowska' \\ 1 Lublin University of Technology, Faculty of Mechanical Engineering, Nadbystrzycka Str. 36, 20-618 Lublin, \\ Poland „, e-mail: j.kuczmaszewski@pollub.pl; p.piesko@pollub.pl; magdalena.michalowska@pollub.edu.pl
}

Received: 2016.04.15

Accepted: 2016.05.10

Published: 2016.06.01

\begin{abstract}
The paper presents an analysis of surface roughness following milling of thin-walled components made of aluminium alloy EN AW-2024, taking into account the three different machining strategies and rolling direction of semi-finished product in the form of a plate combined with the milling feed. The aims of the study were to compare the results of machining using various technologies and show the best of them, providing the smallest roughness of the component following milling, as well as to determine the impact of rolling direction of the plate on the quality of the end surface. Measurement results of surface roughness parameters were provided information about the progress of the machining process.
\end{abstract}

Keywords: machining of aluminium alloys, surface roughness, High Speed Cutting, High Performance Cutting, thin-walled components.

\section{INTRODUCTION}

The thin-walled elements can be defined as the components having thin walls with a thickness of less than $3 \mathrm{~mm}$. Nowadays, they are often referred to as integral elements, characterized by low weight, solid design and high rigidity, among others. Parts are produced from monolithic blocks, particularly aluminium alloys on the new generation of machining centres using modern technologies, i.e. High Speed Cutting and High Performance Cutting. Large quantity of generated chips is the characteristic for machining of these elements (even $95 \%$ of the semi-finished product weight) $[1,3,4]$.

In the industrial practice milling process optimization of thin-walled elements is obtained by [10]:

- selection of an appropriate strategy of machining,

- increased cutting speed $\mathrm{v}_{\mathrm{c}}$,

- „improvement” of technological parameters (in particular feed per tooth $\mathrm{f}_{\mathrm{z}}$ and width of cut $a_{e}$ ), reducing the thrust force which is the component of cutting force acting perpendicular to the work surface.

In each of the above-mentioned techniques it is advised to leave a machining allowance $(0.1 \div$ $0.2 \mathrm{~mm}$ ) to a further finishing method. Essential$1 y$, the number of passes is conditioned by the dimensions of thin-walled element and depth of cut $\mathrm{a}_{\mathrm{p}}$. In addition, it is recommended to use a small ratio $a_{p} / a_{e}$, to shorten the contact time of the tool with the workpiece $[10,13]$.

One of the indicators of the material machinability defined as "the material susceptibility in the specified conditions to change the volume, shapes and dimensions during the machining" is the surface quality $[5,6]$.

Surface quality of elements made of aluminium alloy mainly results from: material properties, process kinematics, machining parameters and external factors related to the stability of the machining process. It has been noted that wrought 
Table 1. Chemical composition and selected properties of alloy EN AW-2024 [11, 12]

\begin{tabular}{|c|c|c|c|c|c|c|c|c|}
\hline \multirow{2}{*}{$\begin{array}{c}\text { Chemical } \\
\text { composition }\end{array}$} & $\mathrm{Si}$ & $\mathrm{Fe}$ & $\mathrm{Cu}$ & $\mathrm{Mn}$ & $\mathrm{Mg}$ & $\mathrm{Cr}$ & $\mathrm{Zn}$ & $\mathrm{Ti}$ \\
\cline { 2 - 9 } & 0.5 & 0.5 & $3.8-4.9$ & $0.3-0.9$ & $1.2-1.8$ & 0.1 & 0.25 & 0.15 \\
\hline \multirow{2}{*}{ Properties } & Density, $\rho$ & \multicolumn{2}{|c|}{ Young's modulus, $\mathrm{E}$} & \multicolumn{2}{c|}{ Tensile strength, $\mathrm{R}_{\mathrm{m}}$} & Yield strength, $\mathrm{Rp}_{0,2}$ & $\begin{array}{c}\text { Brinell } \\
\text { hardness }\end{array}$ \\
\cline { 2 - 9 } & $2.78 \mathrm{~g} / \mathrm{cm}^{3}$ & \multicolumn{2}{|c|}{$73 \mathrm{GPa}$} & \multicolumn{2}{|c|}{$430 \mathrm{MPa}$} & \multicolumn{2}{c|}{$290 \mathrm{MPa}$} & $122 \mathrm{HB}$ \\
\hline
\end{tabular}

alloys exhibit higher strength and hardness and the emerging surface is smoother. In contrast, cast alloys are characterized by a visible impact of the hard particles, which are located in a soft matrix, on the increasing surface roughness. Surface roughness is also related to technological parameters. Feed per tooth $\mathrm{f}_{\mathrm{z}}$ and cutting speed $\mathrm{v}_{\mathrm{c}}$ have a major impact on the quality surface. The cutting tool characteristics such as: blade wear state, geometric parameters and protective coating properties substantially affect the surface smoothness and the cutting force. Cooling method is also an important factor, especially for alloys, for which composition is similar to ,pure” aluminium. The worst surface quality is obtained during machining without cutting fluid $[5,6]$.

Among modern milling technologies there should be mentioned: HSC (High Speed Cutting) and HPC (High Performance Cutting) [2, 6, 9].

On the basis of the literature review comparing High Performance Cutting and High Speed Cutting, one may conclude that $[6,8]$ :

- cutting speed $\mathrm{v}_{\mathrm{c}}$ during HPC is lower than in the case of HSC,

- depth of cut $a_{p}$, width of cut $a_{e}$, feed per tooth $\mathrm{f}_{\mathrm{z}}$ are higher during HPC,

- obtained surface quality following HPC is worse, in comparison to HSC.

These differences result mainly from different purpose of both machining technologies. High Speed Cutting is used for finishing method, while High Performance Cutting is used during roughing operations $[6,7]$.

\section{METHODOLOGY}

The study was conducted for the following aims:

- to compare the results of surface roughness measurements following the different milling strategies of thin-walled elements,

- to verify the hypothesis that the technological history of semi-finished product has an impact on surface roughness following milling (in the present case, rolling direction).

As a part of experimental study, aluminium alloy EN AW-2024 (chemical symbol: EN AWAlCu4Mg1) was machined in the T351 state (heat-treated solution, stress relieved by stretching and aged naturally), characterized by high strength, which is used for a wide range of applications, primarily in the aerospace industry. However, among its disadvantages are: low corrosion resistance and limited weldability.

Chemical composition and selected properties of aluminium alloy EN AW-2024 is given in Table 1.

Samples, which are parallel and perpendicular to the rolling direction, were cut from semifinished product in the form of a plate (thickness $19.05 \mathrm{~mm}$ ). Their overall dimensions are presented in Figure 1.

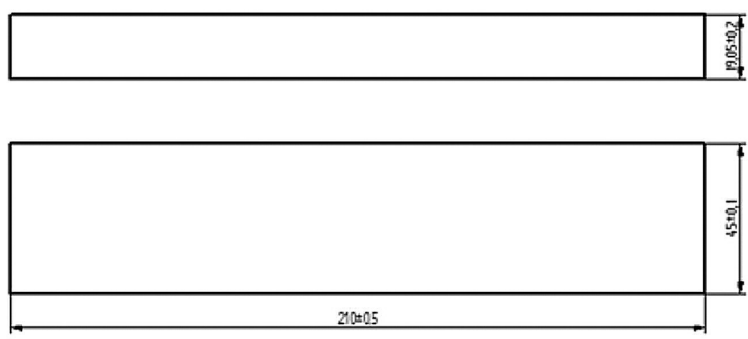

Fig. 1. Overall dimensions of the analyzed samples

Two end mills were used in the experiment:

- indexable end mill of Kennametal (25A03R044B25SED14) with properly selected milling inserts (EDCT140416PDFRLDJ),

- solid end mill of SGS Solid Carbide Tools $(243 \mathrm{CB} 16 \mathrm{~mm} 0,1 \mathrm{R})$ with polished chip flutes.

Figure 2 shows end mill produced by Kennametal (symbol: 25A03R044B25SED14), which was used for high-performance technology HPC and Table 2 presents its specifications.

Milling insert (EDCT140416PDFRLDJ) was selected for tool body produced by Kennametal and is presented in Figure 3, while Table 3 shows its technical data. 


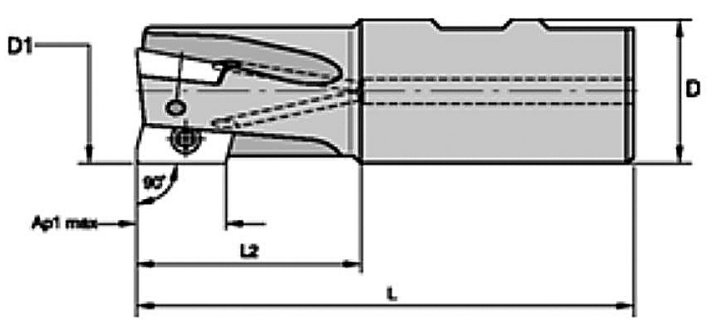

Fig. 2. End mill of Kennametal 25A03R044B25SED14 [14]

Table 2. Technical data of Kennametal end mill 25A03R044B25SED14 [14]

\begin{tabular}{|l|c|}
\hline Symbol & 25A03R044B25SED14 \\
\hline Number of milling inserts $z:$ & 3 \\
\hline Cutting diameter $\mathrm{D}_{1}[\mathrm{~mm}]:$ & 25 \\
\hline Working length $\mathrm{L}_{2}[\mathrm{~mm}]:$ & 44 \\
\hline Overall length $\mathrm{L}[\mathrm{mm}]:$ & 101 \\
\hline Max. depth of cut $\mathrm{a}_{\mathrm{p} 1} \max [\mathrm{mm}]:$ & 14.6 \\
\hline Shrank diameter $\mathrm{D}[\mathrm{mm}]:$ & 25 \\
\hline
\end{tabular}

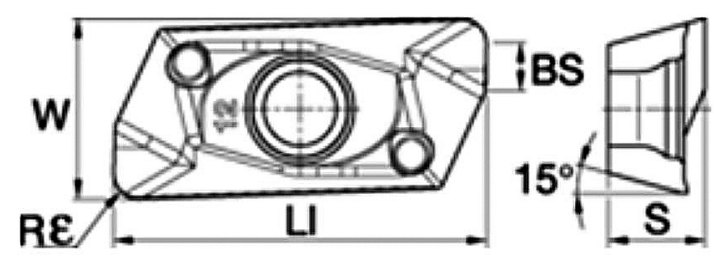

Fig. 3. Milling insert of Kennametal EDCT140416PDFRLDJ [14]

Table 3. Technical data of Kennametal milling insert EDCT140416PDFRLDJ [14]

\begin{tabular}{|l|c|}
\hline Symbol & EDCT140416PDFRLDJ \\
\hline Material: & KC410M \\
\hline Thickness S [mm]: & 4.5 \\
\hline Height W [mm]: & 8.45 \\
\hline Length of wiper edge BS [mm]: & 1.77 \\
\hline $\begin{array}{l}\text { Length of cutting edges } \mathrm{L}_{1} \\
\text { [mm]: }\end{array}$ & 17 \\
\hline Corner radius Re [mm]: & 1.59 \\
\hline Number of cutting edges: & 2 \\
\hline
\end{tabular}

Figure 4 shows solid end mill produced by SGS Solid Carbide Tools (243CB16mm0,1R) with polished chip flutes that was used for conventional finishing method and HSC. Table 4 presents its technical data. Tests were conducted on a vertical machining centre AVIA VMC 800 HS with Heidenhain iTNC 530 CNC system. Special clamping fixture was mounted on the machine table (Fig. 5) to ensures the correct mounting and fixing of analyzed samples.

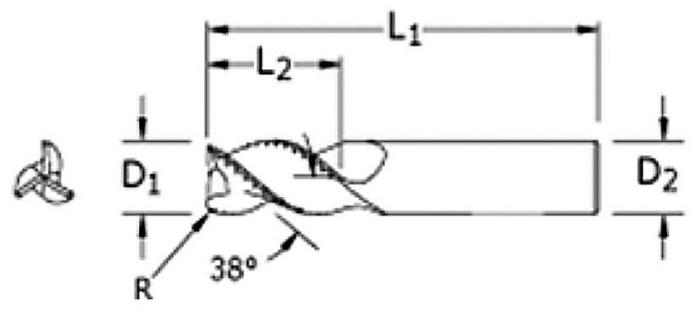

Fig. 4. Solid end mill of SGS Solid Carbide Tools 243CB16mm0,1R [15]

Table 4. Technical data of SGS Solid Carbide Tools end mill 243CB16mm0,1R [15]

\begin{tabular}{|l|c|}
\hline Symbol & 243CB16mm0,1R \\
\hline Number of flutes $z:$ & 3 \\
\hline Cutting diameter $\mathrm{D}_{1}[\mathrm{~mm}]:$ & 16 \\
\hline Length of cut $\mathrm{L}_{2}(\mathrm{ap})[\mathrm{mm}]:$ & 32 \\
\hline Overall length $\mathrm{L}_{1}[\mathrm{~mm}]:$ & 92 \\
\hline Shrank diameter $\mathrm{D}_{2}[\mathrm{~mm}]:$ & 16 \\
\hline Corner radius $\mathrm{R}[\mathrm{mm}]:$ & 1 \\
\hline
\end{tabular}

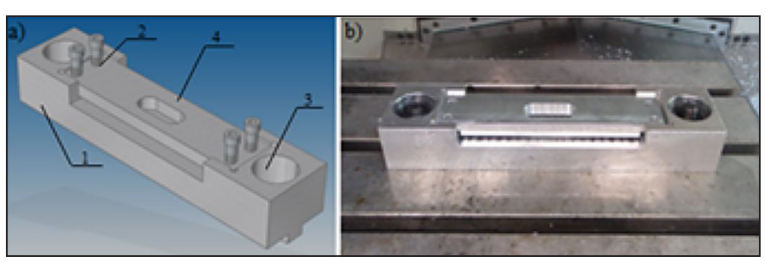

Fig. 5. Special clamping fixture: a) design, b) mounted on the machine table

It consists of:

- main base (1) with milled pocket, four holes for mounting samples using screws (2) and two holes for fixing fixture on the machine table by means of T-slide bolts and nuts (3),

- plate ensuring machining stability (4).

Surface roughness analysis of samples following milling was carried out based on measurements obtained using a contact profilometer - Hommel Tester T1000. The research was conducted after removal of samples from clamping fixture on three levels: two extreme edges (the edge $1: 1=8 \mathrm{~mm}$, the edge $2: 1=$ $152 \mathrm{~mm})$ and in the middle $(1=80 \mathrm{~mm})$. Gauge head of profilometer was always placed in the middle of tool pass and each measurement was repeated ten times (Fig. 6).

Basic parameters of surface roughness measurements of analyzed elements using Hommel Tester T1000 are presented in Table 5.

Arithmetic average of profile ordinates $\mathrm{Ra}$ was adopted for the results analysis of roughness measurements. Conducted study allowed to 


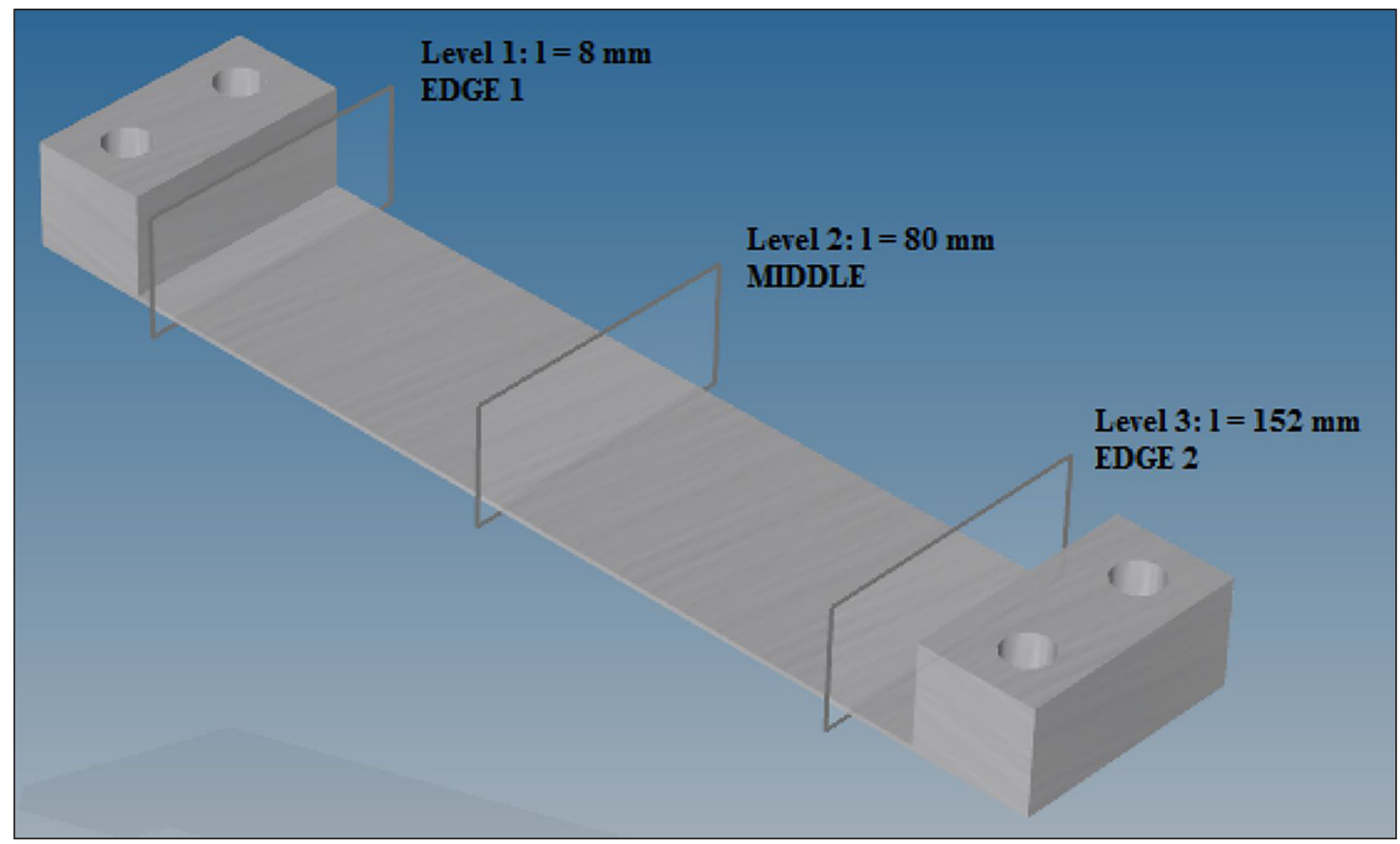

Fig. 6. Schematic layout of the measuring levels

Table 5. Parameters of surface roughness measurements

\begin{tabular}{|l|c|c|}
\hline Measuring conditions & Unit & Value \\
\hline Measuring range: & $\mu \mathrm{m}$ & 80 \\
\hline Measuring length $\mathrm{L}_{\mathrm{t}}:$ & $\mathrm{mm}$ & 4.80 \\
\hline Sampling length $\mathrm{L}_{\mathrm{c}}:$ & $\mathrm{mm}$ & 0,8 \\
\hline Speed $\mathrm{v}_{\mathrm{t}}:$ & $\mathrm{mm} / \mathrm{s}$ & 0.50 \\
\hline Filter: & \multicolumn{2}{|c|}{ ISO 11562 } \\
\hline
\end{tabular}

evaluate surface quality of thin-walled components following milling, including the analyzed strategies and rolling direction of semi-finished product.

Additionally, roughness maps (3D topography) were prepared using 3D Hommel-ETAMIC T8000 RC device in accordance with ISO 25178 (Geometric Product Specifications GPS).
In the framework of experimental study three milling strategies were checked:

- High Performance Cutting,

- High Performance Cutting combined with conventional finishing operation,

- Performance Cutting and High Speed Cutting.

The statement of technological parameters for the above-mentioned technologies is shown in Table 6. Rolling direction of tested samples was the next variable:

- longitudinal - longer edge of samples parallel to plate rolling direction (milling perpendicular to rolling direction),

- transversal - longer edge of samples perpendicular to plate rolling direction (milling parallel to rolling direction).

Table 6. Values of technological parameters for individual machining strategies

\begin{tabular}{|l|c|c|c|c|c|}
\hline \multirow{2}{*}{ Technological parameters } & \multicolumn{4}{|c|}{ Strategies } \\
\cline { 2 - 6 } & HPC & HPC + conventional machining & \multicolumn{2}{c|}{ HPC + HSC } \\
\hline Depth of cut $\mathrm{a}_{\mathrm{p}}[\mathrm{mm}]$ & $3.8^{1)} ;$ & $3.75^{1)} ;$ & 0.2 & $3.75^{1)} ;$ & 4.7 \\
\hline Width of cut $\mathrm{a}_{\mathrm{e}}[\mathrm{mm}]$ & 4.75 & 4.7 & 12 & 18.75 & 12 \\
\hline Cutting speed $\mathrm{v}_{\mathrm{c}}[\mathrm{m} / \mathrm{min}]$ & 18.75 & 18.75 & 200 & 1000 & 1200 \\
\hline Feed per tooth $\mathrm{f}_{\mathrm{z}}[\mathrm{mm} / \mathrm{ostrze}]$ & 1000 & 1000 & 0.02 & 0.1 & 0.02 \\
\hline Rotation speed $\mathrm{n}[\mathrm{obr} / \mathrm{min}]$ & 0.1 & 0.1 & 3979 & 12732 & 23873 \\
\hline Feed speed $\mathrm{v}_{\mathrm{f}}[\mathrm{mm} / \mathrm{min}]$ & 12732 & 12732 & 239 & 3820 & 1432 \\
\hline Number of passes i [-] & 3820 & 3820 & 1 & 4 & 1 \\
\hline
\end{tabular}

1) Value for first pass resulting from plate thickness. 


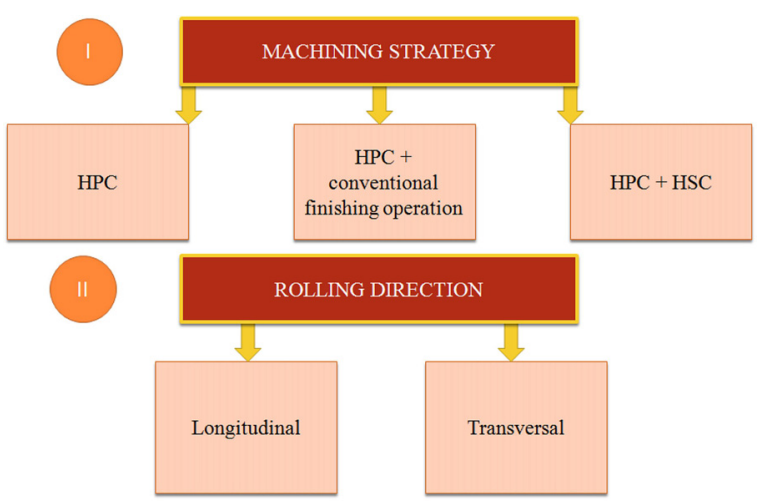

Fig. 7. Schematic diagram of the examined variables

Figure 7 presents a schematic diagram of the examined variables.

In the study, the longitudinal samples were milled with feed that was perpendicular to rolling direction and the transversal - parallel.

\section{RESULTS}

Each series of surface roughness measurements was averaged and the standard deviation was calculated. The results were presented in a graphical form on the bar charts with the designation of all examined variables.

Figure 8 shows values of arithmetic average of profile ordinates $\mathrm{Ra}$ for samples with transversal and longitudinal rolling direction relating to HPC strategy and the three measuring levels. Based on these charts, it was observed that the highest values of Ra parameter were obtained in both cases for the central samples zone: $\mathrm{Ra}=0.41 \mu \mathrm{m}$ (transversal direction) and $\mathrm{Ra}=0.43 \mu \mathrm{m}$ (longitudinal direction). Moreover, for all levels, slightly higher values of Ra were received for samples, which were milled perpendicular to rolling direction.
The values of Ra parameter for samples with transversal and longitudinal rolling direction, which were milled based on HPC strategy combined with conventional machining $(\mathrm{CM})$ as well as measuring levels are presented in Figure 9. On their basis, it was noticed as in Figure 8 that the highest values of Ra were obtained for the middle samples: $\mathrm{Ra}=0.16 \mu \mathrm{m}$ (transversal direction) and $\mathrm{Ra}=0.23 \mu \mathrm{m}$ (longitudinal direction). Additionally, for all levels, the higher values of Ra were received for milled sample with perpendicular feed to rolling direction of plate.

Figure 10 presents the values of arithmetic average of profile ordinates Ra for samples with transversal and longitudinal rolling direction and the combination of two technologies: HSC and HPC as well as examined measuring levels. The highest values of Ra parameter were observed for the middle samples: $\mathrm{Ra}=0.31$ $\mu \mathrm{m}$ (transversal direction) and $\mathrm{Ra}=0.32 \mu \mathrm{m}$ (longitudinal direction). Also in this case, the higher values of Ra parameter were received for sample which was milled perpendicular to the rolling direction.

The values of Ra parameter for individual machining strategies, comparing rolling direction and taking into account center measuring level are shown in Figure 11.

In accordance with the data presented in Fig. 11 it can be noticed that rolling direction has an impact on surface quality. In each case higher values of Ra parameter were obtained for milled samples with feed, which was perpendicular to rolling direction (longitudinal direction).

Arithmetic average of profile ordinates Ra for samples with transversal and longitudinal rolling direction as well as three different machining strategies and center measuring level are shown in Figure 12.
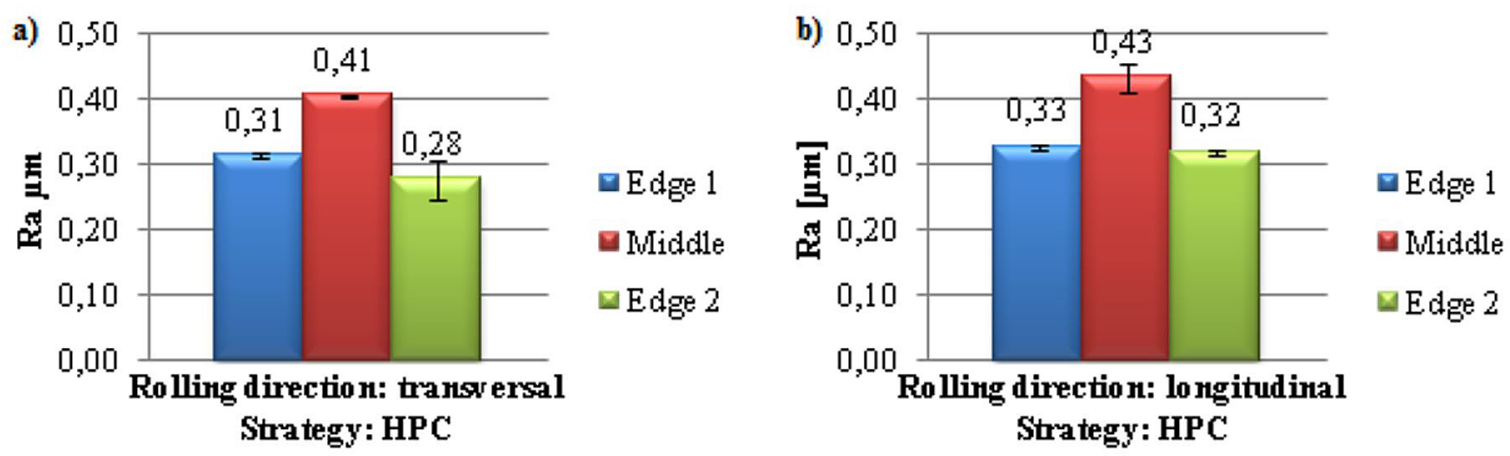

Fig. 8. Arithmetic average of profile ordinates Ra for milled samples: (a) parallel and (b) perpendicular to rolling direction as well as strategy: HPC 

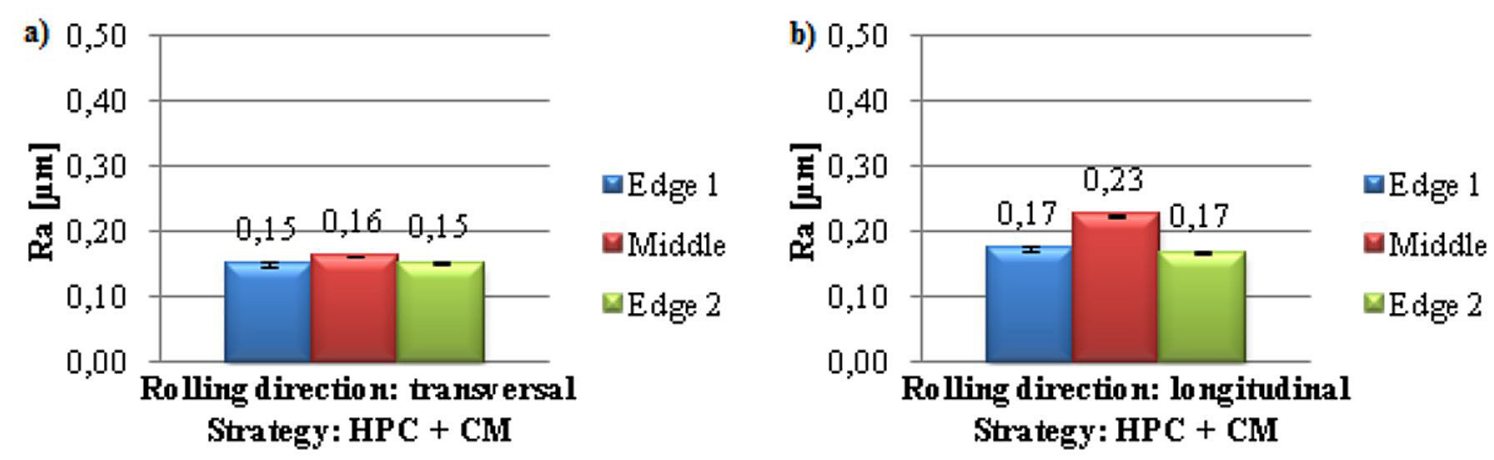

Fig. 9. Arithmetic average of profile ordinates Ra for milled samples: (a) parallel and (b) perpendicular to rolling direction as well as strategy: HPC combined with conventional machining
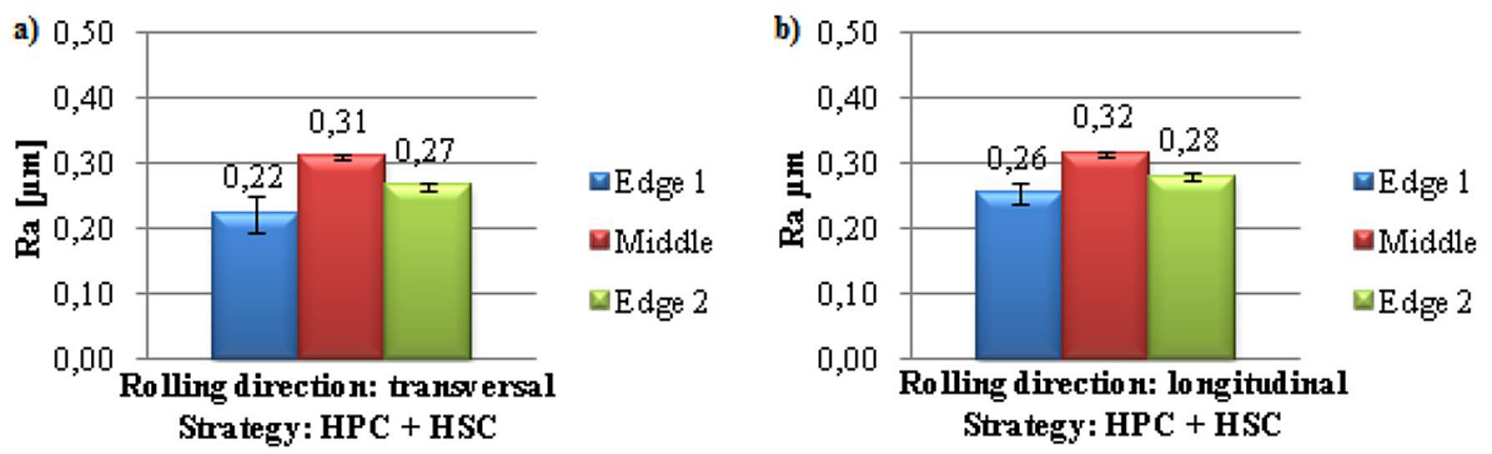

Fig. 10. Arithmetic average of profile ordinates Ra for milled samples: (a) parallel and (b) perpendicular to rolling direction as well as strategy: HPC and HSC
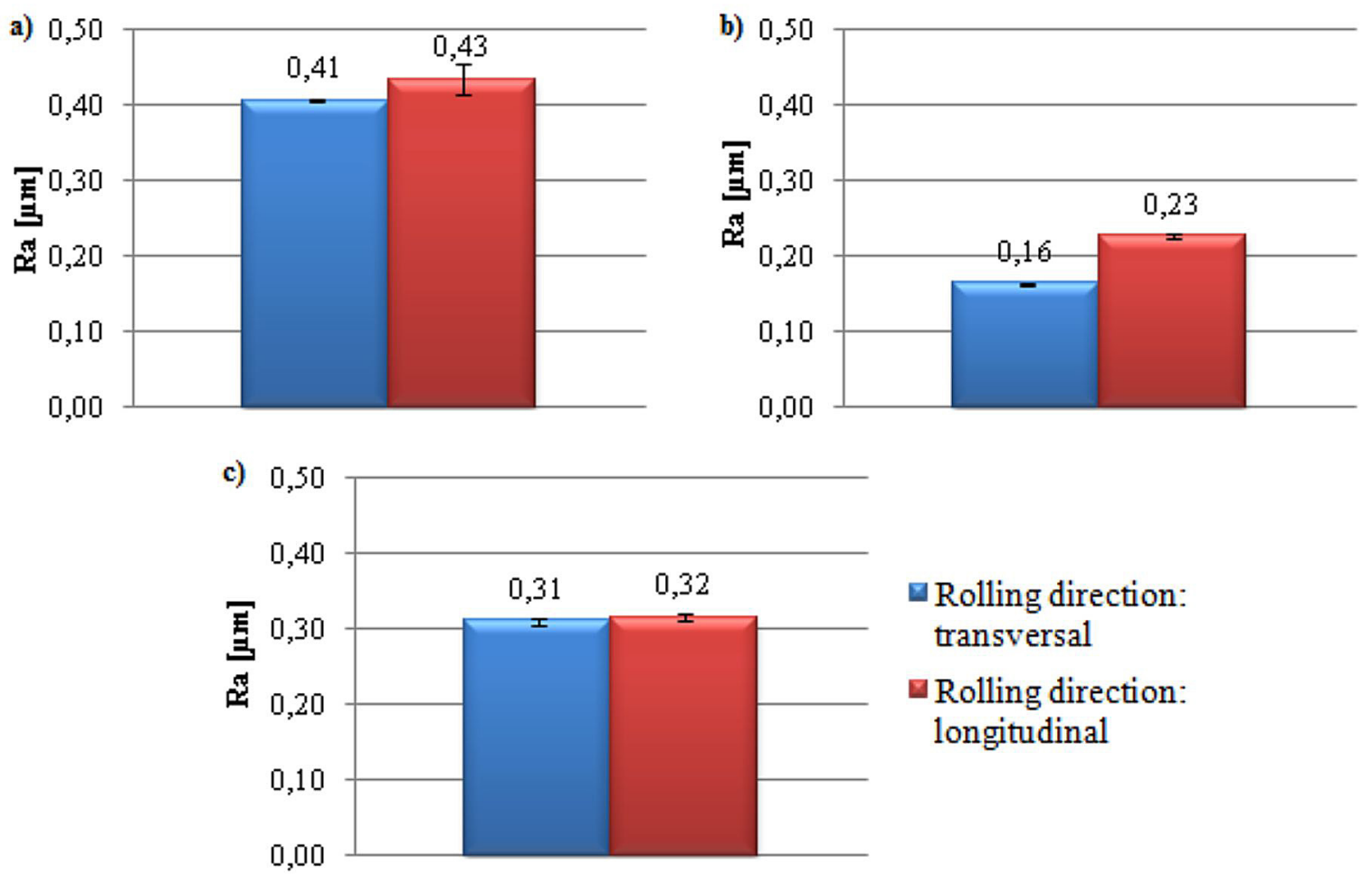

Fig. 11. Arithmetic average of profile ordinates Ra for milled samples: parallel and perpendicular to rolling direction as well as strategies: (a) HPC, (b) HPC combined with conventional machining, (c) HPC and HSC 

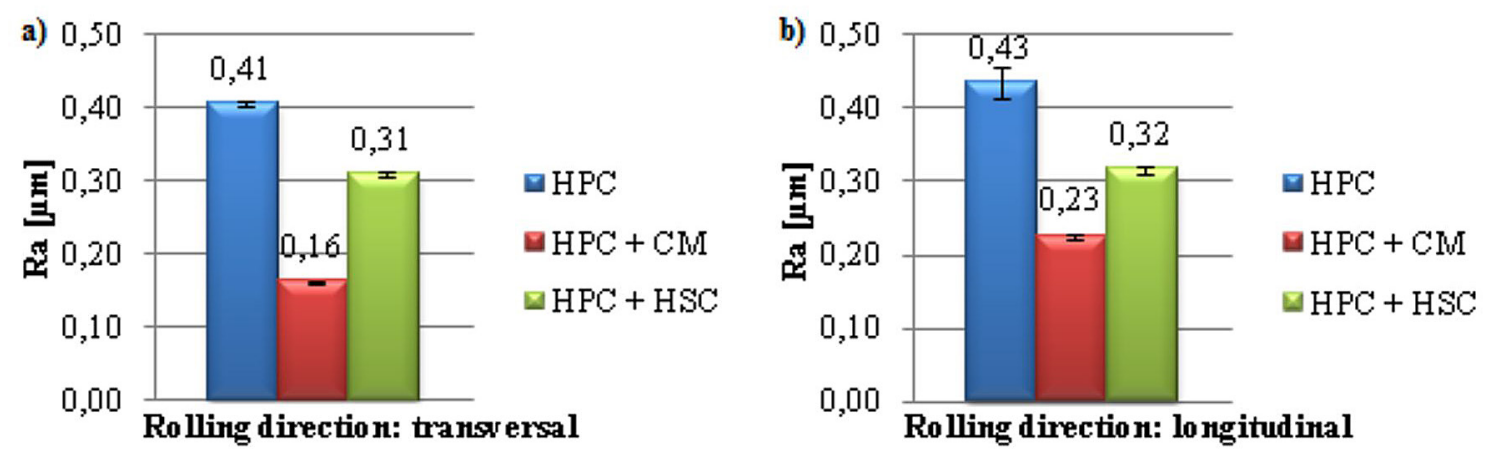

Fig. 12. Arithmetic average of profile ordinates Ra for milled samples: (a) parallel and (b) perpendicular to rolling direction as well as different milling strategies

a)
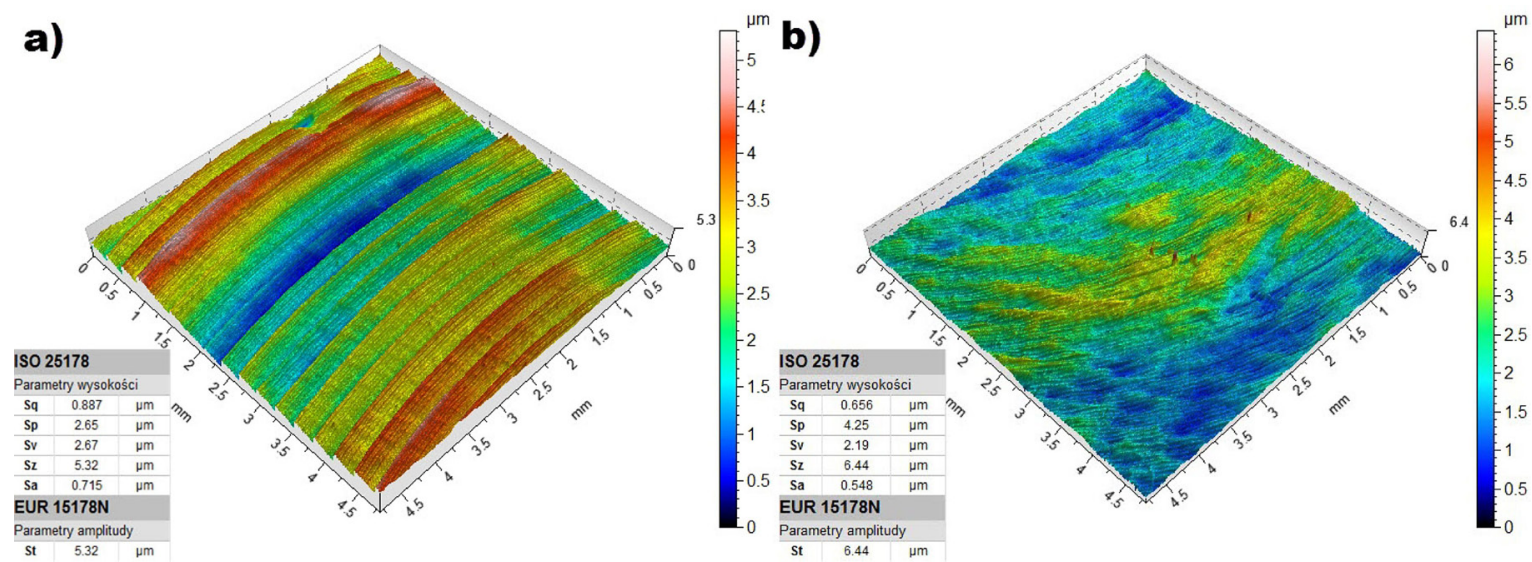

Fig. 13. 3D surface roughness maps for milled samples: (a) perpendicular and (b) parallel to rolling direction, machined using HPC strategy
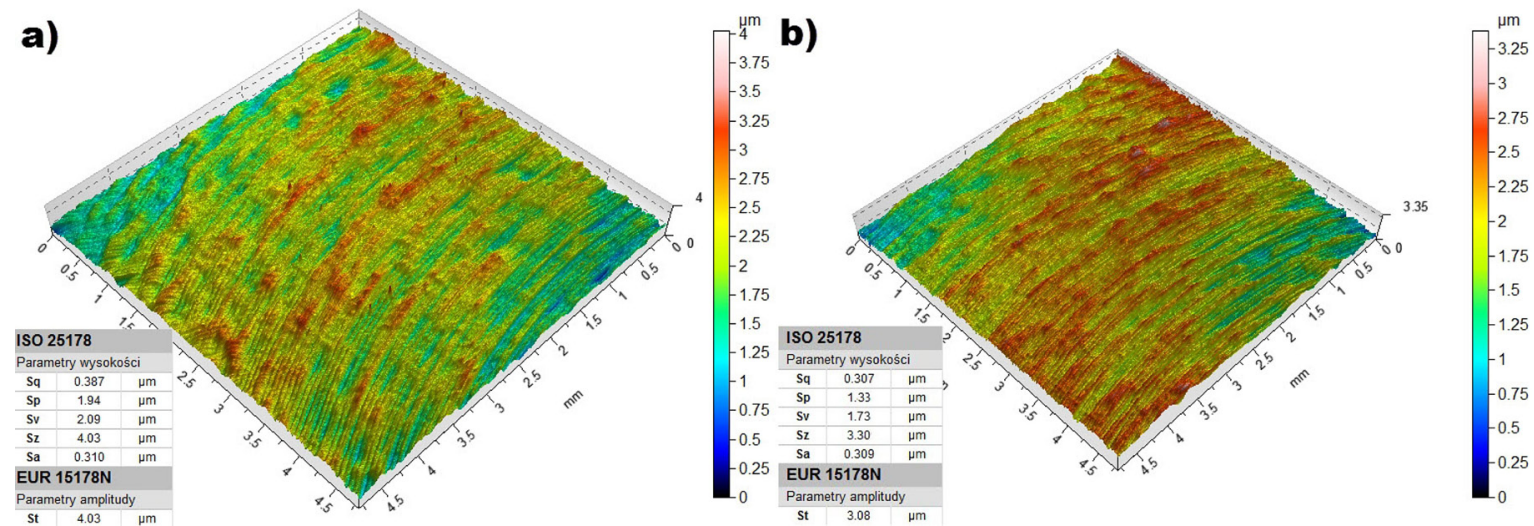

Fig. 14. 3D surface roughness maps for milled samples: (a) perpendicular and (b) parallel to rolling direction as well as High Performance Cutting combined with conventional machining

Comparing results presented in Figure 12, it was noted that the lowest value of Ra parameter was obtained for HPC combined with conventional finishing operation for both variations of rolling direction.

In Figures $13 \div 15$ are shown roughness maps for samples, which were milled perpendicular and parallel to rolling direction, respectively using the examined strategies: HPC, HPC combined with conventional machining, as well as connection of HPC and HSC.

Tables $7 \div 9$ present values of parameters that were obtained during spatial parameters measuring of the examined surface's roughness.

The measuring results of spatial parameters of samples roughness confirmed that the smallest values of roughness were obtained for HPC technology combined with conventional finishing 
a)

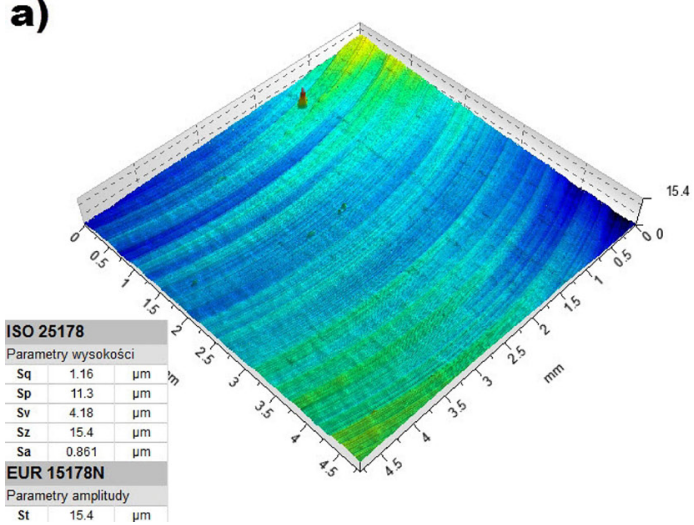

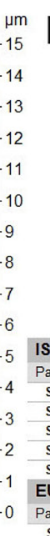

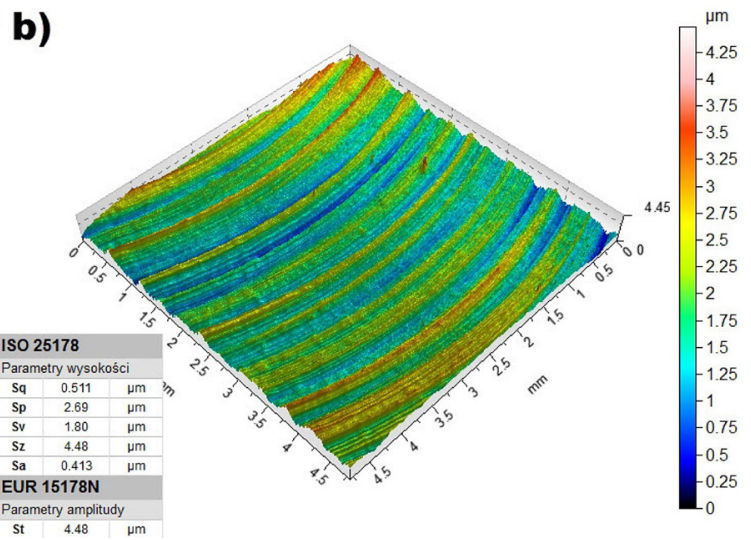

Fig. 15. 3D surface roughness maps for milled samples: (a) perpendicular and (b) parallel to rolling direction, machined using HPC and HSC

Table 7. Values of 3D roughness parameters for samples were milled: (a) perpendicular and (b) parallel to rolling direction, machined using HPC strategy

\begin{tabular}{|c|c|c|}
\hline \multicolumn{3}{|c|}{ ISO 25178} \\
\hline \multicolumn{3}{|c|}{ Height parameters } \\
\hline $\mathrm{Sq}$ & 0.887 & $\mu \mathrm{m}$ \\
\hline Sp & 2.65 & $\mu \mathrm{m}$ \\
\hline Sv & 2.67 & $\mu \mathrm{m}$ \\
\hline $\mathrm{Sz}$ & 5.32 & $\mu \mathrm{m}$ \\
\hline Sa & 0.715 & $\mu \mathrm{m}$ \\
\hline \multicolumn{3}{|c|}{ EUR15178N } \\
\hline \multicolumn{3}{|c|}{ Amplitude parameters } \\
\hline St & 5.32 & $\mu \mathrm{m}$ \\
\hline
\end{tabular}

\begin{tabular}{|c|c|c|}
\hline \multicolumn{3}{|c|}{ b) Height parameters 25178} \\
\hline \multicolumn{3}{|c|}{} \\
\hline $\mathrm{Sq}$ & 0.656 & $\mu \mathrm{m}$ \\
\hline $\mathrm{Sp}$ & 4.25 & $\mu \mathrm{m}$ \\
\hline $\mathrm{Sv}$ & 2.19 & $\mu \mathrm{m}$ \\
\hline $\mathrm{Sz}$ & 6.44 & $\mu \mathrm{m}$ \\
\hline $\mathrm{Sa}$ & 0.548 & $\mu \mathrm{m}$ \\
\hline \multicolumn{3}{|c|}{ EUR15178N } \\
\hline \multicolumn{3}{|c|}{ Amplitude parameters } \\
\hline $\mathrm{St}$ & 6.44 & $\mu \mathrm{m}$ \\
\hline
\end{tabular}

machining and milling with feed, which was parallel to rolling direction.

\section{CONCLUSIONS}

The conducted analysis has allowed to formulate conclusions about the general and practical measures, which could be used to identify the main research directions and their application in industrial practice. Based on the obtained results the following conclusions can be drawn:
Table 8. Values of 3D roughness parameters for samples were milled: (a) perpendicular and (b) parallel to rolling direction as well as High Performance Cutting combined with conventional machining

\begin{tabular}{|c|c|c|}
\hline \multicolumn{3}{|c|}{ ISO 25178} \\
\hline \multicolumn{3}{|c|}{ Height parameters } \\
\hline $\mathrm{Sq}$ & 0.387 & $\mu \mathrm{m}$ \\
\hline Sp & 1.94 & $\mu \mathrm{m}$ \\
\hline Sv & 2.09 & $\mu \mathrm{m}$ \\
\hline $\mathrm{Sz}$ & 4.03 & $\mu \mathrm{m}$ \\
\hline Sa & 0.310 & $\mu \mathrm{m}$ \\
\hline \multicolumn{3}{|c|}{ EUR15178N } \\
\hline \multicolumn{3}{|c|}{ Amplitude parameters } \\
\hline St & 4.03 & $\mu \mathrm{m}$ \\
\hline
\end{tabular}

\begin{tabular}{|c|c|c|}
\hline \multicolumn{3}{|c|}{ ISO 25178} \\
\hline \multicolumn{3}{|c|}{ Height parameters } \\
\hline $\mathrm{Sq}$ & 0.307 & $\mu \mathrm{m}$ \\
\hline Sp & 1.33 & $\mu \mathrm{m}$ \\
\hline Sv & 1.73 & $\mu \mathrm{m}$ \\
\hline $\mathrm{Sz}$ & 3.30 & $\mu \mathrm{m}$ \\
\hline Sa & 0.309 & $\mu \mathrm{m}$ \\
\hline \multicolumn{3}{|c|}{ EUR15178N } \\
\hline \multicolumn{3}{|c|}{ Amplitude parameters } \\
\hline St & 3.08 & $\mu \mathrm{m}$ \\
\hline
\end{tabular}

1. The best surface quality was obtained for High Performance Cutting combined with conventional finishing machining strategy.

2. It can be regarded that during thin-walled components machining, conventional finishing milling with "gentle" removal of material layers has a positive impact on surface quality.

3. For all examined variables, the highest values of Ra parameter were received for the middle level of measuring, mainly due to its farthest distance from the point of fixing material 
Table 9. Values of 3D roughness parameters for samples were milled: (a) perpendicular and (b) parallel to rolling direction, machined using HPC with HSC

\begin{tabular}{|c|c|c|}
\hline \multicolumn{3}{|c|}{ ISO 25178} \\
\hline \multicolumn{3}{|c|}{ Height parameters } \\
\hline $\mathrm{Sq}$ & 1.16 & $\mu \mathrm{m}$ \\
\hline Sp & 11.3 & $\mu \mathrm{m}$ \\
\hline Sv & 4.18 & $\mu \mathrm{m}$ \\
\hline $\mathrm{Sz}$ & 15.4 & $\mu \mathrm{m}$ \\
\hline Sa & 0.861 & $\mu \mathrm{m}$ \\
\hline \multicolumn{3}{|c|}{ EUR15178N } \\
\hline \multicolumn{3}{|c|}{ Amplitude parameters } \\
\hline St & 15.4 & $\mu \mathrm{m}$ \\
\hline
\end{tabular}

\begin{tabular}{|c|c|c|}
\hline \multicolumn{3}{|c|}{ ISO 25178} \\
\hline \multicolumn{3}{|c|}{ Height parameters } \\
\hline $\mathrm{Sq}$ & 0.511 & $\mu \mathrm{m}$ \\
\hline Sp & 2.69 & $\mu \mathrm{m}$ \\
\hline Sv & 1.80 & $\mu \mathrm{m}$ \\
\hline $\mathrm{Sz}$ & 4.48 & $\mu \mathrm{m}$ \\
\hline $\mathrm{Sa}$ & 0.413 & $\mu \mathrm{m}$ \\
\hline \multicolumn{3}{|c|}{ EUR15178N } \\
\hline \multicolumn{3}{|c|}{ Amplitude parameters } \\
\hline St & 4.48 & $\mu \mathrm{m}$ \\
\hline
\end{tabular}

during machining. It was pointed to requirement for precise analysis of the conditions for mounting and fixing thin-walled components in clamping fixture.

4. The differences between the values of roughness that were obtained with the tested strategies are important, because of the practical significance, resulting from the indication of a strategy to ensure the best surface quality (High Performance Cutting combined with conventional finishing machining).

5. The higher values of surface roughness were obtained for milling with feed perpendicular to rolling direction, that indicates the existing relation between rolling direction and feed.

6. Fixing stability plays the key role in thinwalled components machining, as it has a major impact on machined surface quality. During machining of elements with thin walls placement of the supports should be reasonably planned, so as to ensure adequate rigidity of a component in the clamping fixture.

7. The conducted study indicate that both machining direction in relation to rolling direction and milled strategy have a major impact on roughness parameters of tested aluminium alloy EN AW-2024 following milling.

\section{REFERENCES}

1. Ab-Kadir A.R., Osman M.H., Shamsuddin K.A.: A comparison of milling cutting path strategies for thin-walled aluminium alloys fabrication. The Internal Journal of Engineering and Science, 2 (3), 2013, 1-8

2. Adamski W.: Wybrane kierunki zwiększenia wydajności procesów skrawania. Mechanik, 5-6 (82), 2009, 540-546.

3. Adamski W.: Wykorzystanie techniki High Speed Machining przy produkcji części samolotu DREAMLINER Boeing 787. VII Forum „ProCax", Podlesice, 2008.

4. Kuczmaszewski J.: Efektywność wytwarzania elementów lotniczych ze stopów aluminium i magnezu. Komputerowo Zintegrowane Zarządzanie: pod red. Knosala R., Tom II, Oficyna Wydawnicza Polskiego Towarzystwa Zarządzania Produkcją, Opole, 2011, 7-18.

5. Kuczmaszewski J., Zaleski K. (red.): Obróbka skrawaniem stopów aluminium i magnezu. Politechnika Lubelska, Lublin, 2015.

6. Oczoś K.E., Kawalec A.: Kształtowanie metali lekkich. Wydawnictwo Naukowe PWN, Warszawa, 2012.

7. Oczoś K.E.: Obróbka wysokowydajna HPC. Mechanik, 11 (77), 2004, 701-709.

8. Pieśko P., Zagórski I.: Analiza porównawcza metod frezowania HSM, HPC oraz frezowania konwencjonalnego wysokokrzemowych stopów aluminium. Postępy Nauki i Techniki, 7, 2011, 219-226.

9. Zalewski A.: Efektywne wytwarzanie dzięki optymalnej strategii obróbki HSM. Projektowanie i Konstrukcje Inżynierskie, 3 (3), 2007, 23-26.

10. Zębala W.: Minimalizacja błędów obróbki przedmiotów cienkościennych. Inżynieria Maszyn, 3 (15), 2010, 45-54.

11. PN-EN 485-2:2014-02: Aluminium i stopy aluminium. Blachy, taśmy i płyty. Część 2: Własności mechaniczne. Tolerancje kształtu i wymiarów wyrobów walcowanych na zimno.

12. PN-EN 573-3:2010: Aluminium i stopy aluminium. Skład chemiczny i rodzaje wyrobów przerobionych plastycznie. Część 3: Skład chemiczny i rodzaje wyrobów.

13. Machining Guide Sandvik Coromant, 2012.

14. An online catalog of tools produced by Kennametal, http://www.kennametal.com/ (27.11.2015).

15. An online catalog of tools produced by SGS Solid Cabride Tools, http://sgstool.com/ (27.11.2015). 